\title{
Farlige dobbeltforskrivninger
}

\author{
Rydd i Reseptformidleren før du skriver ut en ny resept.
}

En middelaldrende mann kom fra sykehuset og skulle hente ut medisiner på apoteket. I Reseptformidleren fant man blant annet følgende forskrivninger: Atacand (candesartan) $16 \mathrm{mg}$ og $32 \mathrm{mg}$, Candesartan $32 \mathrm{mg}$, Lipitor $10 \mathrm{mg}$ og $20 \mathrm{mg}$ og Selo-Zok $50 \mathrm{mg}$, $100 \mathrm{mg}$ og $200 \mathrm{mg}$. To primærleger og en sykehuslege hadde skrevet ut disse reseptene. Alle tre hadde jobbet i sitt lokale journalsystem, uten å sjekke og rydde i Reseptformidleren.

Dette er et farlig rot. Man kan lure på hva som er å finne av medisiner hjemme hos pasienten, hvilke medisiner han pleier å ta og hvorfor han havnet på sykehus. Man kan også tenke seg at bare SeloZok $200 \mathrm{mg}$ ble utekspedert og at pasienten etter tre måneder ville komme tilbake til apoteket for å hente mer. Da ville bare reseptene på $50 \mathrm{mg}$ og $100 \mathrm{mg}$ være synlige.
Nå som spesialisthelsetjenesten har tatt i bruk elektroniske resepter, er det vanlig at flere leger skriver resepter til samme

\section{«Man kan lure på \\ hva som er å finne \\ av medisiner hjemme \\ hos pasienten»}

pasient. Dette eksemplet er det verste jeg har sett, men som apotekfarmasøyt ser jeg slike «dobbelte» forskrivninger daglig.

Budskapet er: Legene må alltid gå inn i Reseptformidleren og rydde før de skriver ut en ny resept.
Stein Lyftingsmo

stein@lyftingsmo.no

Stein Lyftingsmo (f. 1950) er farmasøyt ved Apotek1 Østbyen, Hamar.

Forfatter har fylt ut ICMJE-skjemaet og oppgir ingen interessekonflikter.

Mottatt 5.12.2016 og godkjent 30.1.2017. Redaktør: Ketil Slagstad.

Publisert først på nett. 